\title{
Correction to: Progress Towards Using Linked Population-Based Data For Geohealth Research: Comparisons Of Aotearoa New Zealand And The United Kingdom
}

\author{
R. A. Oldroyd ${ }^{1,2}$ (1) M. Hobbs ${ }^{3,4} \cdot$ M. Campbell ${ }^{3,5} \cdot$ V. Jenneson ${ }^{1} \cdot$ L. Marek ${ }^{3}$.

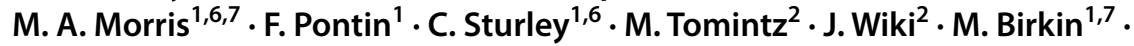 \\ S. Kingham ${ }^{3,5} \cdot$ M. Wilson ${ }^{8}$
}

Published online: 26 August 2021

(c) The Author(s) 2021

\section{Correction to: Applied Spatial Analysis and Policy. https://doi.org/10.1007/s12061-021-09381-8}

Lukas Marek was erroneously omitted from the author list during the copy-editing process. The original author list is incorrect.

The correct author list is presented above.

The original article has been corrected.

The original article can be found online at https://doi.org/10.1007/s12061-021-09381-8.

R. A. Oldroyd

R.Oldroyd@leeds.ac.uk

1 Leeds Institute for Data Analytics, University of Leeds, Leeds, UK

2 School of Geography, University of Leeds, Leeds, UK

3 GeoHealth Laboratory, Geospatial Research Institute, University of Canterbury, Christchurch, Canterbury, New Zealand

4 Health Sciences, College of Education, Health and Human Development, University of Canterbury, Christchurch, Canterbury, New Zealand

5 School of Earth and Environment, College of Science, University of Canterbury, Christchurch, Canterbury, New Zealand

6 School of Medicine, University of Leeds, Leeds, UK

7 Alan Turing Institute, London, UK

8 Geospatial Research Institute, University of Canterbury, Christchurch, Canterbury, New Zealand 
Open Access This article is licensed under a Creative Commons Attribution 4.0 International License, which permits use, sharing, adaptation, distribution and reproduction in any medium or format, as long as you give appropriate credit to the original author(s) and the source, provide a link to the Creative Commons licence, and indicate if changes were made. The images or other third party material in this article are included in the article's Creative Commons licence, unless indicated otherwise in a credit line to the material. If material is not included in the article's Creative Commons licence and your intended use is not permitted by statutory regulation or exceeds the permitted use, you will need to obtain permission directly from the copyright holder. To view a copy of this licence, visit http://creativecommons.org/licen ses/by/4.0/.

Publisher's Note Springer Nature remains neutral with regard to jurisdictional claims in published maps and institutional affiliations. 